\title{
Pengaruh Model Pembelajaran Kooperatif Tipe Think Talk Write Terhadap Hasil Belajar Siswa Pada Materi Menulis Teks Berita
}

\author{
Nurhayati $^{1}$, Mardian $^{2}$, Wahyuni Oktavia ${ }^{3}$ \\ STKIP Singkawang, Singkawang, Indonesia \\ nurynurhayati9393@gmail.com ${ }^{1}$, mardiandeeza@gmail.com² ${ }^{2}$ oktaviawahyuni9@gmail.com ${ }^{3}$
}

\begin{tabular}{l}
\hline \hline Keywords : \\
Teks berita, TTW (think talk write)
\end{tabular}

Keywords :
Teks berita, TTW (think talk write)

\begin{abstract}
Tujuan penelitian ini adalah untuk mengetahui pengaruh model pembelajaran kooperatif tipe TTW (think talk write) terhadap keterampilan menulis teks berita siswa kelas VIII SMP Negeri 12 Singkawang. Metode yang digunakan adalah eksperimen dengan bentuk pree-eksperimental desaign dan jenis one group pre-test dan post-test design. Dalam penelitian ini yang menjadi subjek penelitian adalah siswa kelaas VIII D. Instrumen yang digunakan adalah soal tes hasil belajar yang digunakan sebanyak 2 soal setelah melalui proses uji validasi. Soal dinyatakan valid dengan reliabilitas 0,9 dan dengan kategori sangat tinggi atau layak digunakan. Hasil perhitungan nilai rata-rata hasil tes keterampilan menulis teks berita siswa sebelum menggunakan model pembelajaran TTW (tink talk write) yaitu 56,4. Sedangkan hasil perhitungan nilai rata-rata hasil tes keteramlpilan menulis teks berita siswa setelah menggunakan model pembelajaran TTW (think talk write) mengalami peningkatan yaitu 77,6. Teknik analisis data menggunakan metode staistik uji-t (uji beda). Pengujian uji-t mendapatkan hasil dengan $t_{\text {hitung }}=8,72$ dengan menggunakan taraf signifikansi $\alpha=0,01$, dan $t_{\text {tabel }}=2,69$. Dengan $t_{\text {hitung }}>t_{\text {tabel }}$ atau $8,72>2,69$ maka dapat disimpulkan bahwa terdapat perbedaan keterampilan menulis teks berita dengan model pembelajaran TTW (think talk write) dan dengan tidak menggunakan model pembelajaran TTW (think talk write). Penggunaan model TTW (think talk write) dapat meningkatkan hasil belajar siswa, dengan demikian model TTW ini dapat diterapkan disekolah agar hasil belajar siswa semakin meningkat.
\end{abstract}

\section{PENDAHULUAN}

Pembelajaran bahasa Indonesia dititikberatkan pada empat keterampilan berbahasa. Keempat keterampilan berbahasa ini meliputi keterampilan menyimak (listening skills), keterampilan berbicara (speaking skills), keterampilan membaca (reading skills), dan keterampilan menulis (writing skills). Setiap keterampilan itu erat sekali berhubungan dengan tiga keterampilan lainnya dengan cara yang beraneka ragam. 
Pada penelitian ini, peneliti akan nmeneliti tentang keterampilan menulis. Menulis seperti juga halnya ketiga keterampilan berbahasa lainnya, merupakan suatu proses perkembangan. Menulis menuntut pengalaman, waktu, kesempatan, pelatihan, keterampilan-keterampilan khusus, dan pengajaran langsung menjadi seorang penulis. Hal ini sesuai dengan pendapat kellog (dalam Suwarti, 2011:75) bahwa kecakapan menulis tingkat anvanced (tujuan) merupakan sebuah aspek penting dalam prestasi akademis sebagaimana juga prestasi terkait dengan tugas.

Pembelajaran menulis harus diajarkan, dibina, dan dikembangkan secara intensif disemua jenjang pendidikan. Menulis teks berita merupakan satu diantara kompetensi yang harus dikuasai oleh siswa. Hal ini sesuai dengan standar kompetensi (SK) 12 yaitu mengungkapkan informasi dalam bentuk rangkuman, teks berita dan slogan/poster. Adapun kompetensidasar (KD) 12.2 menulis teks berita secara singkat, padat, dan jelas dalam Kurikulum Tingkat Satuan Pendidikan (KTSP).

Keterampilan menulis teks berita adalah suatu bentuk teks yang diajarkan untuk melatih siswa agar bisa mengembangkan keterampilan menulisnya lewat kejadian-kejadian yang mereka lalui dikehidupan nyata. Menurut Syahraini (2014:89) Menulis berita merupakan keterampilan yang menuntut proses berpikir karena adanya unsure-unsur $5 \mathrm{~W}+1 \mathrm{H}$ yang harus dikembangkan menjadi beberapa paragraf hingga menjadi sebuah berita. Dari menulis teks berita itu pula bisa belajar memberikan informasi kepada orang lain dengan menggunakan bahasa yang menarik. Dalam hal ini materi menulis teks berita sangat penting untuk diajarkan. Masih ada penulis temui, pada materi menulis teks berita ini nilai yang didapat siswa tidak mecapai KKM yang telah ditentukan oleh sekolah yaitu 70 .

Pemilihan keterampilan menulis teks berita menggunakan model TTW (Think Talk Write) disebabkan oleh beberapa hal. Pertama, keterampilan menulis merupakan satu diantara keterampilan berbahasa yang harus dikuasai oleh siswa, terutama keterampilan menulis teks berita. Kedua, siswa merasa kesulitan untuk membuat teks berita dalam mengembangkan gagasannya. Penggunaan model TTW (Think Talk Write) dalam menulis teks berita akan membantu siswa untuk membuat teks berita dengan bahasa yang menarik melalui berpikir, berdiskusi dan kemudian dituangkan dimedia tulis. Yamin dan Ansari (dalam putri, 2019:71) menyatakan teknik TTW (think talk write) adalah salah satu teknik pembelajaran yang dapat meningkatkan aktivitas dan komunikasi di antara siswa.

Berdasarkan wawancara di SMP Negeri 12 Singkawang melalui wawancara dari guru mata pelajaran bahasa Indonesia yaitu IbuSuharti, A.Md. Pada kelas VIII terdiri dari empat kelas dengan jumlah 98 siswa. Pada materi menulis teks berita, rata-rata nilai siswa tidak mencapai KKM. Kelas VIII A hanya mencapai 60,4\%, kelas VIII B 58,1\%, kelas VIII C 56,5\%, dan kelas VIII D 55,9\%. Jadi rata-rata nilai siswa pada materi menulis teks berita 57,7\%. Dari keadaan tersebut menimbulkan asumsi peneliti bahwa hal-hal tersebut dapat terjadi karena guru belum menggunakan model pembelajaran yang cocok untuk materi menulis teks berita yang pada akhirnya berdampak hasil belajar siswa yang rendah.

Berdasarkan latar belakang tersebut, maka yang menjadi permasalahan umum dalam penelitian ini adalah "Bagaimanakah pengaruh model TTW (Think Talk Write) terhadap hasil belajar siswa pada materi menulis teks berita siswa kelas VIII SMP Negeri 12 Singkawang tahun ajaran 2017/2018". Masalah khusus penelitian ini bagaimanakah hasil belajar siswa dalam materi menulis teks berita sebelum menggunakan model TTW (Think Talk Write) pada siswa kelas VIII SMP Negeri 12 Singkawang, bagaimanakah hasil belajar siswa dalam materi menulis teks berita setelah menggunakan model TTW (Think Talk Write) pada siswa kelas VIII SMP Negeri 12 Singkawang, dan apakah terdapat pengaruh model TTW (Think Talk Write) terhadap menulis teks berita pada siswa kelas VIII SMP Negeri 12 Singkawang?

Berdasarkan masalah tersebut, tujuan khusus dari penelitian ini adalah untuk mengetahui pengaruh model TTW (think Talk Write) terhadap hasil belajar siswa pada materi menulis teks berita siswa kelasVIII SMP Negeri 12 Singkawang. Adapun tujuan umum dari penelitian ini yaitu mengetahui 
tentang kemampuan menulis teks berita pada siswa kelas VIII SMP Negeri12 Singkawang sebelum menggunakan model pembelajaran TTW (Think Talk Write), kemampuan menulis teks berita pada siswa kelas VIII SMP Negeri12 Singkawang sesudah menerapkan model TTW (Think Talk Write), dan pengaruh model TTW (Think Talk Write) terhadap hasil belajar siswa materi menulis teks berita pada siswa kelas VIII SMP Negeri12 Singkawang.

Manfaat teoritis dari penelitian ini adalah hasil penelitian ini diharapkan agar dapat menjadi bahan dan sumber bacaan bagi mahasiswa maupun praktisi pendidikan. Adapun manfaat praktisnya adalah peneliti mampu mengetahui kelemahan penyebab terhambatnya pemahaman menulis siswa kelas VIII SMP Negeri 12 Singkawang, sebagai referensi untuk meningkatkan penggunaan metode pembelajaran yang sesuai dan bervariasi bagi guru, embantu siswa dalam memahami materi pelajaran serta dapat mendorong siswa untuk meningkatkan semangat kerjasama mereka serta meningkatkan motivasi belajar siswa sehingga peningkatan hasil belajar siswa dalam proses pembelajaran bahasa Indonesia, hasil penelitian ini diharapkan dapat diimplementasikan sekolah untuk bisa mencari solusi dalam permasalahan yang terjadi pada pembelajaran, dan penelitian ini dapat bermanfaat sebagai bahan referensi kepustakaan dan sebagai bahan masukan bagi lembaga untuk ikut serta dalam memperhatikan aspirasi dan motivasi dalam melakukan aktivitas penelitian.

Model pembelajaran TTW (Think Talk Write) adalah strategi yang memfasilitasi latihan berbahasa secara lisan dan menulis bahasa tersebut dengan lancar (Huda, 2014:218), menulis adalah menurunkan atau melukiskan lambang-lambang grafik yang menggambarkan suatu bahasa yang dipahami oleh sesorang, sehingga orang-orang lain dapat membaca lambang-lambang grafik tersebut kalau mereka memahami bahasa dan gambaran grafik itu (Tarigan, 2008:22), dan berita adalah sebuah informasi yang penting dan menarik perhatian serta minat khalayak pendengar (Sumadiria, 2011:64). Berdasarkan dari definisi operasional tersebut dapat disimpulkan bahwa penggunaan model TTW (Think Talk Write) dapat menumbuhkembangkan kemampuan menulis siswa.

\section{METODE}

Jenis yang digunakan dalam penelitian ini adalah penelitian kuantitatif. Penelitian ini disebut kuantitatif karena data yang diolah berupa angka-angka. Hal ini sejalan dengan pendapat Arikunto (dalam Margaresy, 2018:364) yang mengemukakan bahwa penelitian kuantitatif adalah penelitian yang menggunakan angka, dimulai dari pengumpulan data, kemudian penafsiran dan terakhir ditampilkan hasilnya. Dalam penelitian ini, peneliti menggunakan metode eksperimen. Menurut

Mahmud (2011:106) menyatakan bahwa metode eksperimen adalah satu-satunya metode penelitian yang dianggap paling tepat untuk menguji hipotesis mengenai hubungan sebab akibat. Secara sistematis dan logis, metode ini menjawab pertanyaan "Jika penyelidikan dilakukan pada kondisikondisi yang dikontrol dengan teliti, apakah yang terjadi?". Sumanto, (dalam H. Mahmud 2011:106) menyatakan bahwa metode eksperimental merupakan metode penelitian yang memungkinkan peneliti memanipulasi variabel dan meneliti akibat-akibatnya. Sedangkan menurut Sugiono (2015:107) menyatakan bahwa metode eksperimen dapat diartikan sebagai metode penelitian yang digunakan untuk mencari pengaruh perlakuan tertentu terhadap yang lain dalam kondisi yang terkendalikan.

Bentuk penelitian yang digunakan dalam penelitian ini adalah bentuk penelitian pree-eksperimental desaign dengan jenis One Group Pre-test dan Post-Test Design. Menurut Sugiyono (2013: 109-110) dikatakan pree-xperimentaldesign, karena desain ini belum merupakan eksperimen sungguh-sungguh dan masih ada variabel luar yang ikut berpengaruh terhadap terbentuknya variabel dependen. Jadi hasil eksperimen yang merupakan variabel dependen bukan semata-mata dipengaruhi oleh variabel independen. Hal ini dapat terjadi karena tidak adanya variabel kontrol, dan sampel tidak dipilih secara random. 
Dalam penelitian ini menggunkan dua variabel yaitu variabel bebas dan varabel terikat. Variabel bebas adalah variabel yang diasumsikan menjadi penyebab munculnya variabel lain. Adapun variabel bebas dalam penelitian ini adalah penggunaan model TTW (Think Talk Write). Variabel terikat variabel yang kemunculannya diasumsikan disebabkan oleh variabel bebas. Adapun variabel teriakat dalam penelitian ini adalah "hasil belajar menulis teks berita pada siswa kelas VIII SMP Negeri 12 Singkawang".

Rancangan dalam penelitian ini adalah tahap I siswa diberikan pre-test tanpa diadakan perlakuan terlebih dahulu, hal ini dilakukan untuk mengetahui hasil belajar siswa sebelum diberikannya perlakuan (treatment). Tahap II siswa diberikan perlakuan dengan menggunakan model TTW (Think Talk Write) pada saat kegiatan belajar mengajar sedang berlangsung. Tahap III siswa diberikan posttest setelah diadakan perlakuan (treatment). Hal ini dilakukan untuk mengetahui hasil penggunaan model TTW (Think Talk Write) dalam meningkatkan hasil.Populasi dalam penelitian ini adalah seluruh siswa kelas VIII SMP Negeri 12 Singkawang. Sampel yang akan diambil dalam penetian ini adalah kelas VIII D dengan jumlah siswa sebanyak 23 orang.

Teknik yang digunakan dalam peneliti ini adalah teknik pengukuran. Teknik pengukuran bersifat mengukur karena menggunakan instrumen standar atau telah distandardisasikan, dan menghasilkan data hasil pengukuran yang berbentuk angka-angka. Menurut Lien (dalam Hamdani, 2011:299) menyatakan bahwa pengukuran merupakan sejumlah data yang dikumpulkan dengan menggunakan alat ukur yang objektif untuk keperluan analisis dan interpretasi. Adapun instrumen penelitian itu adalah tes hasil belajar. Pengertian tes menurut Jihad dan Haris (dalam Sulaeman, 2018:210) tes merupakan himpunan pertanyaan yang harus dijawab, harus ditanggapi, atau tugas yang harus dilaksanakan oleh orang yang di tes. Tes diberikan untuk memperoleh data tentang hasil belajar siswa pada materi menulis teks berita. Dalam penelitian ini tes diberikan sebelum dan sesudah perlakuan (treatment), hal ini dilakukan untuk mengetahui perbedaan hasil belajar siswa sebelum dan sesudah diberikan perlakuan.

Teknik Analisis data diartikan sebagai upaya mengolah data menjadiinformasi, sehingga karakteristik atau sifat-sifat data tersebut dapat dengan mudah dipahami dan bermanfaat untuk menjawab masalahmasalah yang berkaitan dengan kegiatan penelitian. Maka dari itu, teknik analisis data sangatlah penting untuk dilakukan dalam proses penelitian. Sebab, dari analisis yang dilakukan peneliti dapat mengambil kesimpulan atas apa yang telah dilakukan. Untuk menganalisis data yang diperoleh dari sebuah penelitian, maka dikemukakan langkah-langkah. Untuk menjawab sub masalah kesatu dan kedua, yaitu menghitung rata-rata hasil belajar siswa pada materi menulis teks berita digunakan rumus rata-rata. Dan untuk menjawab masalah ketiga akan dilihat dari hasil posttest dan pretest, uji yang digunakan adalah t-test. Sebelum digunakan dengan t-test maka terlebih dahulu akan dilakukan uji prasyarat analisis data dengan menggunakan ui normalitas dan uji homogenitas data.

\section{HASIL DAN PEMBAHASAN}

Setelah melakukan penelitian, peneliti menghitung hasil dari penelitian tersebut. Adapun hasil tes sebelum dan sesudah menggunakan model TTW (think talk write) adalah pre-test dengan rata-rata 56,4 dan post-test dengan rata-rata 77,6. Hasilnya terdapat perbedaan nilai siswa antara pre-test dan post-test yakni dengan selisih 21,2. Itu artinya, setelah siswa menggunakan model pembelajaran TTW (think talk write) maka nilai siswa akan mengalami kenaikkan. Untuk lebih jelasnya, berikut tabel hasil tes pre-test dan post-test siswa.

Tabel 1. hasil tes pre-test dan post-test

\begin{tabular}{ccccc}
\hline NO & & Pretest & Posttest \\
\hline 1 & Jumlah & 1240,9 & & 1707,6 \\
2 & Rata-rata & 56,4 & & 77,6 \\
3 & Selisih & & 21,2 & \\
\hline
\end{tabular}


Setelah mengetahui hasil nilai siswa pada pretest dan posttest dan terdapat peningkatan, selanjutnya peneliti akan melakukan uji untuk mengetahui apakah terdapat pengaruh model pembelajaran TTW (think talk write) pada keterampilan menulis teks berita. Hasil pengaruh model pembelajaran TTW (think talk write) terhadap keterampilan menulis teks berita siswa diperoleh dari data pretest dan posttest dengan menggunakan uji-t. namun sebelum melakukan uji-t, terlebih dahulu melakukan uji prasyarat yaitu uji normalitas data dan uji homogenitas data. Uji normalitas dilakukan untuk memenuhi satu diantara uji prasyarat uji-t dan untuk mengetahui sampel yang diteliti berdistribusi normal atau tidak. Pengujian normalitas menggunakan uji ci-kuadrat. Kriteria pengambilan keputusan adalah jika $x_{\text {hitung }}^{2}<x_{\text {tabel }}^{2}$ maka data berdistribusi normal. Sedangkan jika $x_{\text {kitung }}^{2}>x_{\text {tabel }}^{2}$ maka data tidak berdistribusi normal. Hasil analisis uji normalitas untuk data pretest dan posttest siswa dapat dilihat pada tabel berikut ini.

Tabel 2. Hasil analisis uji normalitas

\begin{tabular}{cccc}
\hline Tes & $x_{\text {hitung }}^{2}$ & $x_{\text {tabel }}^{2}$ & Keterangan \\
\hline Pretest & $-144,607$ & 9,21 & Normal \\
Posttest & 96,67 & 9,21 & Normal \\
\hline
\end{tabular}

Berdasarkan dari tabel tersebut yaitu Nilai $x_{\text {hitung }}^{2}=-112,617$, karena pada taraf signifikan $\alpha=0,01$ diketahui $x_{\text {tabel }}^{2}=9,21$ maka $-144,607<9,21$ sehingga data pretest berdistribusi norma. Nilai $x_{\text {hitung }}^{2}$ data posttest adalah 96,67, karena pada taraf signifika $\alpha=0,01$ diketahui $x_{\text {tabel }}^{2} 9,21$ maka 96,67< 9,21 sehingga data posttest berdistribusi normal.

Pada perhitungan sebelumnya data pada pretest dan postest berdistribusi normal. Selanjutnya melakukan uji homogenitas untuk mengetahui apakah pretest dan posttest homogen atau tidak. Kriteria pengambilan keputusan uji homogenitas adalah jika $f_{\text {hitung }}<f_{\text {tabel }}$ maka data homogen. Sedangkan jika sebaliknya $f_{\text {hitung }}>f_{\text {tabel }}$ maka data tidak homogen. Hasil analisis uji homogenitas yang dilakukan dengan data pretest dan posttest pada tabel berikut ini.

Tabel 3. Hasil analisis uji homogenitas

\begin{tabular}{cc}
\hline$f_{\text {hitung }}$ & $f_{\text {tabel }}$ \\
\hline 0,375 & 31,82 \\
\hline
\end{tabular}

Dari tabel tersebut yaitu uji homogenitas $f_{\text {hitung }}=0,375$ sehingga $f_{\text {hitung }}<f_{\text {tabel }}$ atau $0,375<31,82$, maka dapat disimpulkan bahwa nilai pretest dan posttest homogen. Setelah uji normalitas dan uji homogenitas data sebagai prasyarat uji-t terpenuhi maka selanjutnya melakukan perhitungan uji-t. Uji$\mathrm{t}$ yang digunakan adalah uji-t independen. Kriteria pengujian $t_{\text {hitung }}>t_{\text {tabel }}$ maka tidak terdapat perbedaan peningkatan keterampilan menulis tes berita siswa menggunakan model pembelajaran TTW (think talk write). Sebaliknya jika $t_{\text {hitung }}<t_{\text {tabel }}$ maka terdapat perbedaan peningkatan keterampilan menulis teks berita siswa menggnakan model pembelajaran TTW (think talk write). Hasil perihitungan uji-t independen dapat dilihat pada tabel berikut.

Tabel 4. Hasil perihitungan uji-t

\begin{tabular}{cc}
\hline$t_{\text {hitung }}$ & $t_{\text {tabel }}$ \\
\hline 8,72 & 2,69 \\
\hline
\end{tabular}

Dari tabel tersebut yaitu Nilai $t_{\text {hitung }}$ pada pretest dan posttest adalah 8,72 dan berdasarkan $\alpha=0,01$ diperoleh $t_{\text {tabel }}=2,69$. Sesuai kriteria pengujian, $t_{\text {hitung }}>t_{\text {tabel }}$ atau $8,72>2,69$ maka dapat 
disimpulkan bahwa terdapat perbedaan keterampilan menulis teks berita siswa menggunakan model pebelajaran TTW (think talk write).

Hasil penelitian yang telah dilakukan di SMP Negeri 12 Singkawang menyatakan bahwa populasi kelas VIII dengan jumlah siswa 88 siswa. Sampel yang diambil adalah kelas VIIID dengan jumlah siswa 22 siswa. Tujuan dari penelitian ini ada tiga. Pertama, Kemampuan menulis teks berita pada siswa kelas VIII SMP Negeri 12 Singkawang sebelum menggunakan model pembelajaran TTW (Think Talk Write. Kedua, Kemampuan menulis teks berita pada siswa kelas VIII SMP Negeri 12 Singkawang sesudah menerapkan model TTW (Think Talk Write). Ketiga, Pengaruh model TTW (Think Talk Write) terhadap hasil belajar siswa materi menulis teks berita pada siswa kelas VIII SMP Negeri 12 Singkawang.

Hasil penelitian yang telah dilakukan di SMP Negeri 12 Singkawang menyatakan bahwa populasi kelas VIII dengan jumlah siswa 88 siswa. Sampel yang diambil adalah kelas VIIID dengan jumlah siswa 22 siswa. Tujuan dari penelitian ini ada tiga. Pertama, Kemampuan menulis teks berita pada siswa kelas VIII SMP Negeri 12 Singkawang sebelum menggunakan model pembelajaran TTW (Think Talk Write. Kedua, Kemampuan menulis teks berita pada siswa kelas VIII SMP Negeri 12 Singkawang sesudah menerapkan model TTW (Think Talk Write). Ketiga, Pengaruh model TTW (Think Talk Write) terhadap hasil belajar siswa materi menulis teks berita pada siswa kelas VIII SMP Negeri 12 Singkawang. Hasil belajar siswa sebelum menggunakan model pembelajaran TTW (think talk write) masih sangat rendah. KKM yang ditentukan untuk mata pelajaran Bahasa Indonesia yaitu 75 sedangkan hasil yang didapat siswa dengan rata-rata hanya 56,4 dari 22 siswa. Berikut diagram hasil belajar siswa sebelum menggunakan model TTW (think talk write).

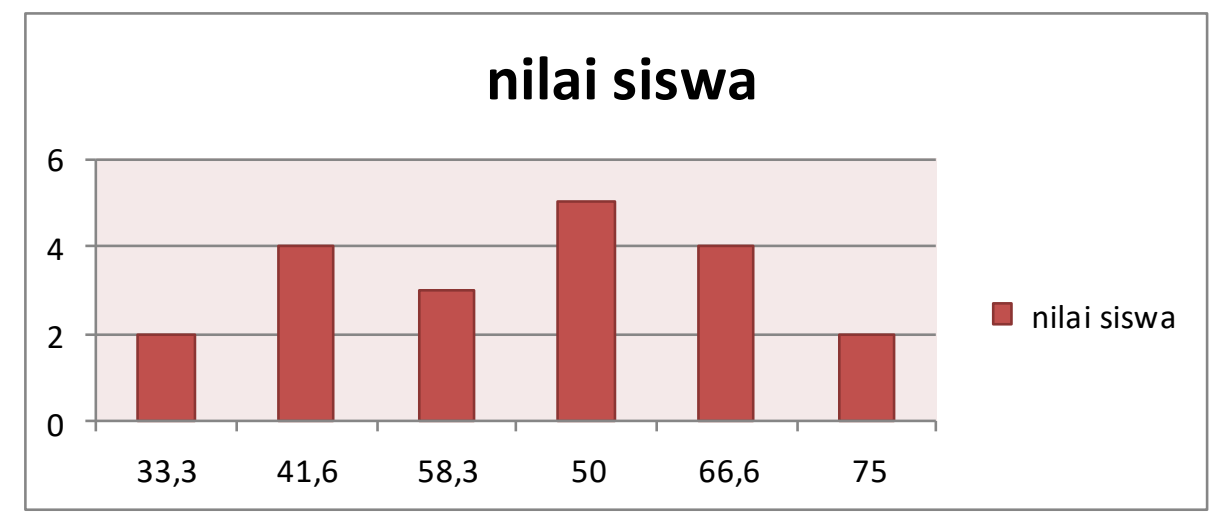

Gambar 1 hasil belajar siswa

Hasil belajar siswa sesudah menggunakan model pembelajaran TTW (think talk write) mengalami peningkatan yang signifikan. KKM yang ditentukan untuk mata pelajaran Bahasa Indonesia yaitu 75. Hasil nilai siswa sesudah menggunakan model pembelajaran TTW (think talk write) yaitu dengan ratarata 77,6 dari 22 siswa. Berikut diagram hasil belajar siswa sebelum menggunakan model TTW (think talk write). 


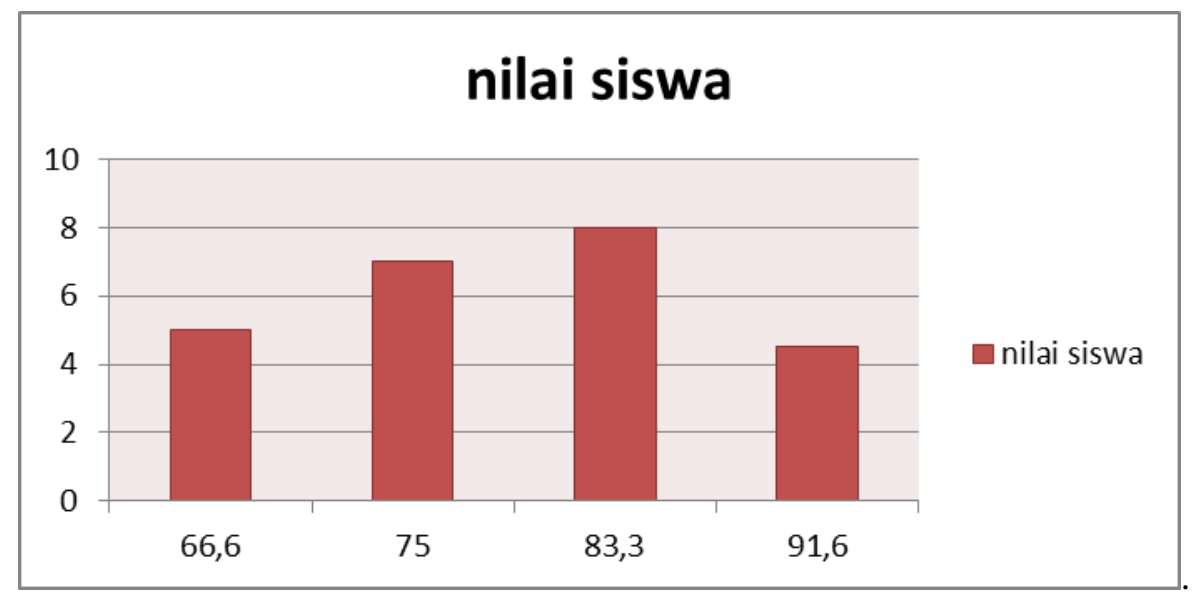

Gambar 2 presentasi nilai siswa

Setelah dilakukan analisis hasil tes keterampilan menulis teks berita pada siswa, hasil penelitian menunjukkan bahwa pembelajaran dengan menggunakan model pembelajaran koopertif tipe TTW (think talk write) berpengaruh terhadap keterampilan menulis teks berita siswa. hal tersebut ditunjukkan dari hasil pre-test dan post-test siswa yaitu pre-test dengan rata-rata 56,4 dan post-test dengan rata-rata 77,6. Terdapat perbedaan nilai keterampilan menulis teks berita siswa yang diberi perlakuan dengan mengunakan model pembelajaran TTW (think talk write) yang diterapkan dikelas VIII D dan siswa yang tidak diberi perlakuan dengan menggunakan model pembelajaran TTW (think talk rite) hal ini terbukti pada pengujian dengan uji-t dengan membandingkan nilai $t_{\text {hitung }}$ dan $t_{\text {tabel }}$ kemudian diperoleh nilai $t_{\text {kitung }}>t_{\text {tabel }}(8,72>2,69)$ yang berarti terdapat perbedaan peningkatan yang signifikan pada keterampilan menulis teks berita siswa dengan model pembelajaran TTW (think talk write) dan dengan tidak diberikan perlakuan dengan menggunakan model TTW (think talk write). Dapat disimpulkan bahwa model pembelajaran menggunakan model pembelajaran kooperatif tipe TTW (think talk write) berpengaruh terhadap keterampilan menulis teks berita siswa kelas VIII.

\section{KESIMPULAN DAN SARAN}

Berdasarkan hasil pengolahan data penelitian yang telah dilakukan, secara umum dapat disimpulkan bahwa hipotesis Ho ditolak dan Ha diterima. Berkait hipotesis tersebut maka terdapat pengaruh penggunaan model pembelajaran kooperatif tipe (think talk write) TTW terhadap kemampuan menulis teks berita kelas VIII SMP Negeri12 Singkawang. Dari kesimpulan permasalahan umum tersebut, dapat disimpulkan beberapa bagian sub-sub masalah yaitu (1) Hasil belajar siswa pada materi menulis teks berita sebelum diberi perlakuan dapat disimpulkan masih rendah. Hal ini dapat dibuktikan dengan nilai rata-rata hasil tes kemampuan menulis teks berita siswa yaitu dengan nilai rata-rata pretest 56,4 dan posttest 77,6. (2) Hasil belajar siswa pada materi menulis teks berita sesudah diberi perlakuan dengan menggunakan model pembelajaran tipe (think talk write) TTW mengalami peningkatan. Seperti yang telah dijelaskan diatas yaitu sebelum diberi perlakuan nilai rata-rata siswa rendah dibandingkan nilai siswa yang telah diberi perlakuan.nilai rata-rata pretest 56,4 dan nilai rata-rata posttest 77,6. (3) Terdapat pengaruh model pembelajaran kooperatif tipe (think talk write) TTW terhadap hasil pembelajaran pada materi menulis teks berita kelas VIII. Hal ini dibuktikan dalam perhitungan $t_{\text {hitung }}>t_{\text {tabel }}$ atau $8,72>2,1$ maka dapat disimpulkan bahwa terdapat perbedaan keterampilan menulis teks berita dengan model pembelajaran TTW (think talk write) dan dengan tidak menggunakan model pembelajaran TTW (think talk write).

Peneliti memberikan beberapa saran dalam penelitian yang berjudui pengaruh model pembelajaran kooperatif tipe TTW (think Talk Write) terhadap hasil belajar siswa pada materi keterampilan menulis teks berita kelas VIII SMP Negeri 12 Singkawang tahun ajaran 2017/2018 yaitu (1) Model pembelajaran kooperatif tipe TTW (think talk write) dapat menjadi satu diantara alternatif dalam 
pembelajaran bahasa indonesia untuk mningkatkan kemampuan menulis teks berita. (2) Mengimplementasikan model pembelajaran koopertatif tipe TTW (think talk write) maka hendaknya menggunakannya sesuai dengan tujuan pendidikan agar dapat meningkatkan hasil belajar siswa dengan baik dan menerapkan model pembelajaran yang menarik dalam setip proses belajar mengajar agar dapat mendapatkan hasil yang optimal. (2) Dengan menggunakan model TTW (think talk write) harus lebih kreatif dalam menyajikan pembelajaran bahasa indonesia agar pmbelajaran bahasa indonesia lebih menarik dan tidak menimbulkan kebosanan bagi siswa.

\section{DAFTAR PUSTAKA}

Hamdani. 2011. Strategi Belajar Mengajar. Bandung: Pustaka Setia.

Huda Miftahul. 2014. Model-model Pengajaran dan Pembelajaran. Yogyakarta: Pustaka Belajar.

Mahmud. 2011. Metode Penelitian Pendidikan. Bandung: Pustaka Setia.

Margaresy, T. 2018. Pengaruh Model Pembelajaran Kooperatif Tipe Think Talk Write terhadap keterampilan menulis teks persuasi siswa kelas VIII SMP Negeri 1 Batu Sangkar. Jurnal Pendidikan Bahasa dan Sastra Indonesia, 7(3), 362-369.

Putri, R.D. 2019. Pengaruh Penggunaan Teknik Talk Write (TTW) Terhadap Keterampilan Menulis Teks Fabel Siswa Kelas VII SMP Negeri 31 Padang. Jurnal Pendidikan Bahasa dan Sastra Indonesia, 8(2), 66-73.

Rasyid, Harun dan Mansur. 2009. Penilaian Hasil Belajar. Bandung: Wacana Prima.

Riyanto, Yatim. 2010. Metodologi Penelitian Pendidikan. Surabaya: SIC.

Sugiyono. 2015. Metode Penelitian Pendidikan. Bandung: Alfabeta.

Sulaeman, A. 2018. Pengaruh Penggunaan Model Pembelajaran Examples Non-examples Terhadap Hasil Belajar Menulis Teks Berita pada Siswa Kelas VIII SMP N 14 Kota Tangerang. SilampariBisa, 1(2) 201.

Sumadiria, Haris. 2011. Jurnalistik Indonesia. Bandung:Simbiosa Rekatama Media

Suwarti. 2011. Upaya Peningkatan Kemampuan Menulis Teks Berita Siswa Kelas VIII pada SMP Negeri 1 Bringin Melalui Model Pembelajaran Kontekstual Berbasis Lingkungan. Jurnal Penelitian Humaniora, 12(1), 74-90.

Syahraini, E. 2014. Peningkatan Keterampilan Menulis Teks Berita Melalui Pendekatan Kontekstual Siswa Kelas VIII H SMP Negeri 4 Tambang Kabupaten Kampar. Jurnal Bahasa, Sastra dan pembelajaran 2(2).

Tarigan, Hendry Guntur. 2008. Menulis. Bandung: Angkasa. 